\title{
A RESEARCH ON THE ROLE OF CONSUMER INVOLVEMENT AND PRODUCT KNOWLEDGE LEVELS ON PURCHASING DECISIONS ${ }^{1}$
}

Gözde KANDEMİ²

Serdar PIRTINI ${ }^{3}$

Azra BAYRAKTAR ${ }^{4}$
Received Date (Başvuru Tarihi): 20/08/2019

Accepted Date (Kabul Tarihi): 15/09/2019

Published Date (Yayın Tarihi): 16/09/2019

ABSTRACT
Keywords:
Consumer
Involvement, Product
Knowledge Level,
Information Search
and Purchase
Intention

Jel Codes: M31, M39
The aim of the research is to examine the relationship between consumer involvement and product knowledge level with utilitarian (smartphone) and hedonic (cosmetic) products and their purchasing decisions. In this study, data were collected by using survey method which is widely used in data collection in marketing researches. The research was conducted with 456 university students. Factor analysis, independent t test, one way variance (ANOVA) and correlation analysis were used in the study. When the results of the research were examined, it was found out that the perception of the men was statistically high for the interest, hedonic value, the importance of perceived risk and the product knowledge levels for information search and purchasing intention factors. In research on cosmetic products, involvement in consumer interest variable, hedonic value and sign value factors of products and product knowledge level, perception of women in information search and purchase intention were significantly higher.

\section{TÜKETICİ IILGILENIM VE ÜRÜN BILGİ DÜZEYLERININ SATIN ALMA KARARLARI ÜZERINDEKI ROLÜNE ILLIŞKINN BİR ARAŞTIRMA}

\section{ABSTRACT}

Anahtar Kelimeler: Tüketici Illgilenimi, Ürün Bilgi Düzeyi, Bilgi Arama Niyeti, Satın Alma Niyeti,

\section{Jel Kodlart:}

M31, M39
Araştırmanın amacı, tüketicilerin faydacı (akıllı telefon) ve hedonik (kozmetik ürünler) ürünlerle ilgili sahip olduklart tüketici ilgilenimi ve bilgi düzeylerinin, satın alma kararlarıyla olan ilişkisini incelemektir. Bu çalışmada veriler, pazarlama araştırmalarında veri toplamada yaygın olarak kullanılan anket yöntemi ile toplanmıştır. Araştırma 456 üniversite öğrencisi ile yapılmıştır. Araştırmada faktör analizi, bağımsız t testi, tek yönlü varyans (ANOVA) ve korelasyon analizi kullanılmıştır. Araştırma sonuçları incelendiğinde akıllı telefonlar ile ilgili yapılan araştırmada tüketici ilgilenimi ölçeği içerisinde olan ilgi, hedonik değer, algllanan riskin önemi faktörleri ile ürün bilgi düzeylerinin bilgi arama ve satın alma niyeti faktörleri için erkeklerin algısının istatistiki açıdan anlamlı düzeyde yüksek olduğu sonucu ortaya çıkmıştır. Kozmetik ürünlerle ilgili yapılan araştırmada yapılan ttesti analizinde tüketici ilgilenimi değişkeni içerisinde yer alan ilgi, ürünlerin hedonik değeri ve işaret değeri faktörleri ile ürün bilgi düzeyi, bilgi arama ve satın alma niyetleri değişkenlerinde kadınların algısı istatistiki açıdan anlamlı düzeyde yüksektir.

\footnotetext{
1 This study; Gözde Kandemir "A Research on the Role of Consumer Interest and Product Knowledge Levels on Purchase Decisions" is made from the master's thesis entitled.

2 Doctorate Student, Marmara University, Institute of Social Sciences, Marketing Department, Turkey, ggozdekandemirr@gmail.com . https://orcid.org/0000-0002-6346-1619 3 Prof. Dr., Marmara University, Faculty of Business, Department of Business Administration, Turkey, serdarpirtini@marmara.edu.tr https://orcid.org/0000-0002-9858-060X

4 Prof. Dr., Marmara University, Faculty of Business, Department of Business Administration, Turkey, abayraktar@marmara.edu.tr
} 


\section{INTRODUCTION}

One of the oldest and most widely accepted principles of the theory of consumer behavior is that consumers should be considered separately as they have different needs and different structures. In addition, several researchers have suggested that the perceived severity for any particular product will vary among consumers (Bloch \& Richins, 1983; Krugman, 1966; Zaichkowsky, 1986; Michaelidou \& Dibb, 2008; Hanzaee, Khoshpanjeh, \& Rahnama, 2011). Successful marketing begins with understanding how and why consumer behavior is a turning point for all marketing activities of consumers. Analyzing the factors affecting consumer behavior and analyzing the amount of the effect on the consumer's behavior will lead to the recognition and understanding of the consumer's behavior and thus to provide a more adaptable product with consumer needs. The problem that companies face is not the lack of products, the lack of customers. Therefore, it is important to know the customer but it is not easy to achieve this. Marketing theorists have long debated whether companies that focus on customer needs are better positioned than companies that do not achieve long-term success. For the services the service provider's ability to satisfy the customer's request, expectation and needs of the service determines the degree of customer satisfaction (Hanzaee \& Mirvaisi, 2011, p. 133). However, for the consumer's attitude and sense towards a product often depends on the product characteristics. There are factors that lead to the search and purchase intention of information resulting from the perceived value of the products. Marketing researchers focus on these factors that influence the choice of consumers.

In this study, factors affecting the decision of smartphone consumers in Turkey and cosmetics are being investigated. According to Kapferer and Laurent (1985), involvement affects the general process of consumer decision-making, from the acquisition of initial knowledge to the final evaluation of the product purchased (Kapferer \& Laurent, 1985, p. 42). In order to understand consumer behavior, it is extremely important to understand the structure of the consumer's involvement, and it is often intended to understand the consumer's behavior on a particular subject.

Most researchers think that this variable is the most important variable, especially due to high predictive value in purchasing behavior (Choubtarash, Mahdieh, \& Marnani, 2013, p. 278-291). On the other hand, product knowledge also plays an important role in consumer behavior because consumers with different levels of knowledge behave differently. Therefore, this study emphasizes the product knowledge along with the consumer involvement variable. It 
has been demonstrated in studies that it is an important structure in understanding consumer behaviors such as information search and information processing (Bettman \& Park, 1980; Brucks, 1985; Rao \& Monroe, 1988; Sujan, 1985).

Today, with the prominence of digitalization, the ways of getting information and searching have started to increase. Therefore, determining the extent to which information the consumers have had to search for information or to purchase intention is an important step for marketing efforts. The other important issue of the research is the intention of the information search and the intention of the purchase. An evoked consumer can search for more information. If the consumer has a strong and satisfying product under his hands, the consumer is more likely to buy. If the product is unsatisfactory, the consumer can only store the need for memory or undertake a search for information about the need (Kotler \& Armstrong, 2010, p. 254). Overall, the main purpose of this research is to assess the relationship between consumer involvement and product knowledge levels with information search and purchase intentions.

\section{LITERATURE REVIEW}

\subsection{Consumer Behavıors And Involvement In Purchasing Process}

The consumer's interest in purchasing a product or service is always dependent on the purchase request and also the willingness to pay for the product (Tekin, Yiltay, \& Ayaz, 2016). Although consumers have the willingness and ability to pay for the product, consumers can be influenced by psychological factors, personal factors, cultural factors, social factors, impact of family members, economic factors, and social media change the purchasing decisions with the effect of various factors. These factors represent the values, preferences, perceptions and ideologies of a particular community. 


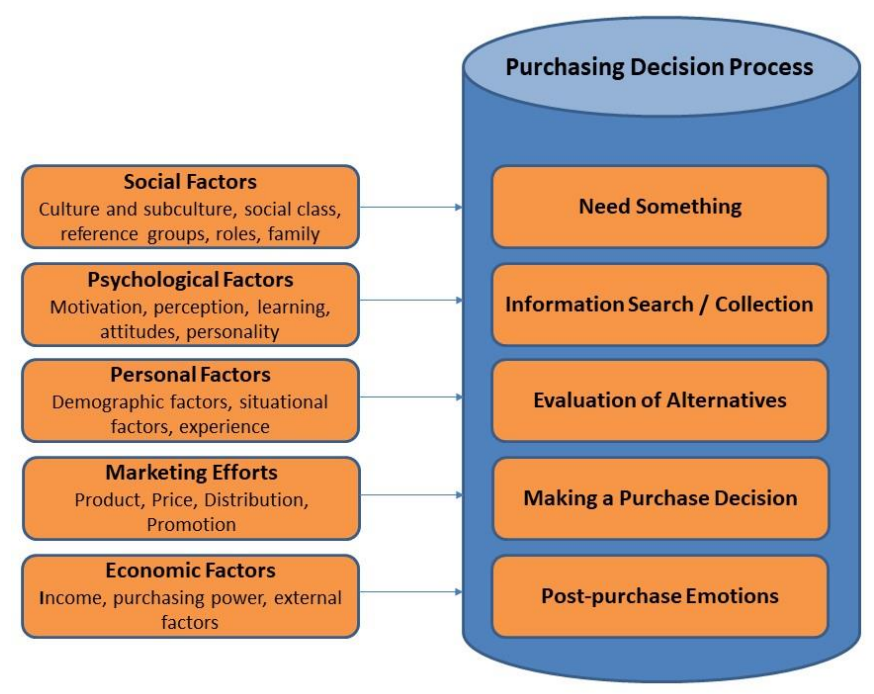

Figure 1. Factors Influencing Purchase Decision Process

Source: (Kotler \& Keller, 2012, s. 161)

At an early age, buyers learn to recognize acceptable behaviors and choices when choosing their products. Personal characteristics such as age, profession, economic conditions, lifestyle and personality of the consumer have a major impact on purchasing decisions and behaviors. Social factors and social status, including the group to which the customer belongs, also affect purchasing decisions. Human beings are social from birth. They must interact with them and make decisions. Social groups such as families, opinion leaders can influence consumers' purchasing decisions. A person's purchasing decisions are influenced by psychological factors such as motivation, perception, and learning. Many theories have been developed to explain that consumer behavior makes different decisions within the same needs. Motivation refers to processes that explain why people behave like this. To the extent that there is a perceived link between the needs, goals or values of the consumer and product information, the consumer will be motivated to pay attention to product information. When the relevant information is activated in memory, a motivation state is created that guides the behavior (eg shopping). At this point, involvement can be seen as motivation to process information (Solomon M. R., 2010).

With increasing involvement in a product, the consumer places more emphasis on product-related advertising and various sources of information. The consumer makes more cognitive effort to understand the given information and focuses more on the product-related information. (Solomon, Bamossy, Askegaard, \& amp; Hogg, 1999, p. 106). Obtains sufficient 
information from a variety of information sources (Reference Resources, Womm, e-Womm, Idea Leaders, Advertisements, Salespeople, etc.) about which product to choose.

When the studies on consumer involvement and product knowledge are examined in the literature, Park and Moon (2003, p.978), he argued that consumer involvement is one of the controversial issues in the research of social sciences related to consumer behavior. The aim of their study is to examine how theoretically compelling features (product type and product information type) affect the correlation between consumer product involvement and consumer product knowledge. The results suggest that the correlation between a consumer's product involvement and objective product knowledge is higher in a utilitarian product than a hedonic product. Conversely, the correlation between a consumer's product involvement and subjective product knowledge showed that a hedonic product was higher than a utilitarian product (Park \& Moon, 2003, p. 977).

\subsection{Conceptualization of Involvement}

Involvement stems from the notion of self-interest, which expresses the relationship between social psychology and an 'individual, issue or object (Michaelidou \& Dibb, 2006). The definitions related to involvement in marketing literature emerge as a result of the studies of my self (Ego) by Sherif and Cantril (1947). Ego concern (sometimes referred to as enduring involvement) implies the importance of the product to the concept of self. This concept means a high level of social risk: Failure to perform the desired function of the product may cause damage to the self-concept of the consumer (Solomon, Bamossy, Askegaard, \& Hogg, 1999, p. 109). Involvement in marketing has emerged with the work of Krugman in 1966. In Krugman study, involvement is defined as the number of links between the individual, the content of the persuasive stimulus, and the content of his or her life within a minute, as well as the clues of conscious bridging or the number of links of personal references (Krugman, 1966, p. 564). Involvement is defined in several categories. The dimensions and types of the research are given in Figure 2. These dimensions and species will be discussed in the continuation of the study. 


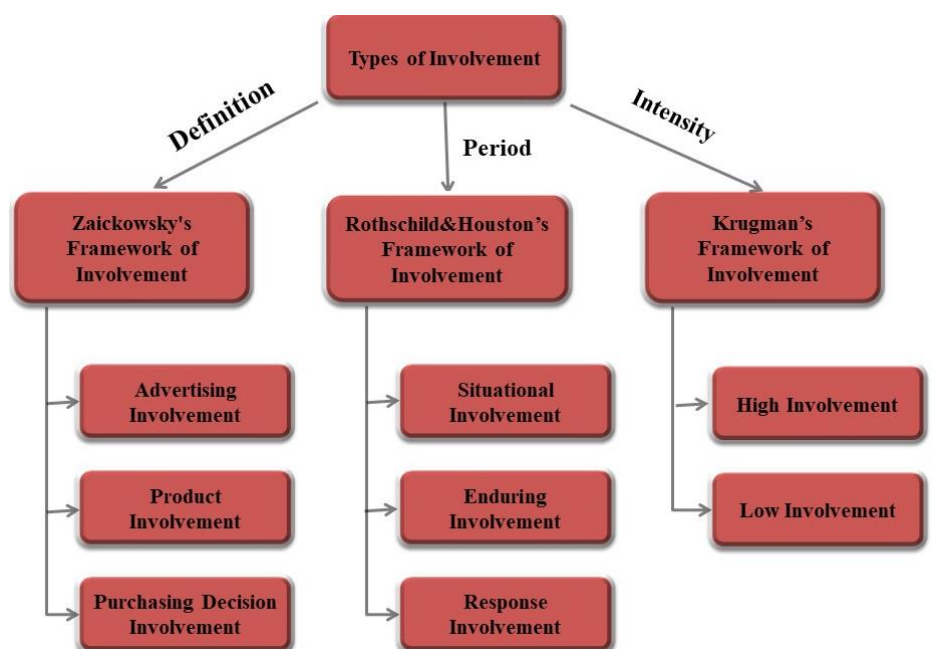

Figure 2. Dimensions and Types of Involvement

Source: (Zaichkowsky, 1986; Houston \& Rothschild, 1977; Krugman, 1965)

Zaickowsky's Framework of Involvement: Zaickowsky (1986), in his study, this dimension of the type of care that comes to the foreground object with the "definition" that emerged. (Zaichkowsky, 1986). The identification (address) of involvement relates to the stimulus generating this perception; A product category (tangible or intangible) can be a certain product or brand, advertising, purchase decision (Cabañero, 2006, p. 76).

- Product Involvement: Product involvement is defined as an unobservable situation that reflects the amount of interest, arousal, or emotional commitment that a particular product raises in the individual (Bloch, 1982, p. 413).

- Advertising Involvement: The involvement structure has emerged as an important factor measuring the effectiveness of advertising. In studies, involvement is an interim variable that generally refers to determining whether the advertisement is effective on the buyer (Zaichkowsky, 1986, p. 4).

- Purcasing Decision Involvement: It can be defined as the size of interest and concern that a consumer is willing to undertake to make a purchase decision (Mittal, 1989, p. 150).

Rothschild\&Houston's Framework of Involvement: Rothschild and Houston have dealt with the length dimension of involvement in their work. The length refers to the timing and there are three types: enduring involvement, situational involvement and response involvement (Cabañero, 2006, p. 76).

- Situational Involvement: It is the degree of involvement that is stimulated by a particular situation, such as the custody of the purchase, and the situation, as well as product 
characteristics (including product cost, product complexity and similarity between selection alternatives). Therefore, situational concern arises from perceived risk (Bloch \& Richins, 1983, p. 70).

- Enduring Involvement: Higie \& Feick, in their study, have identified enduring involvement as products or activities that have the potential to stimulate the individual, causing continuous personal attention. They stated that enduring involvement is the motivation of the product or the activity, the use of the product, or the degree to which the pleasure of entering an activity is related to the individual's own image or thoughts (Higie \& Feick, 1989, p. 690).

- Response Involvement: Express a behavioral orientation that includes knowledge and decision processes. A third form of involvement is a reactionary response that takes a behavioral view that reflects the extent to which individuals are involved in a situation. This kind of behavior may occur in the form of caution, price awareness or warning of brand differences (Michaelidou \& Dibb, 2008, p. 93).

Krugman's Framework of Involvement: Krugman (1965) measures the size of the ads and measures the intensity of involvement. The intensity of involvement relates to the perceived level of involvement of the consumer, for each person and to a certain degree or level, which is completely subjective. (Cabañero, 2006, p. 76). Inolvement directly affects perceived system quality, but only indirectly affects consumer satisfaction, perceived individual impact (McGill, \& Klobas,2008).

- Low Involvement: Under low involvement conditions the information is taken as a whole and choices are made without creating a high level of awareness.

- High involvement: Under high-involvement conditions, information processing and deliberate selection ocur (Kassarjian, 1981, p. 33).

\subsection{Product Knowledge Levels Of Consumer Behavıors}

The important role of consumer information in the consumer decision-making process has long been known in the literature and has been studied in various studies. It has been shown in studies that it is an important structure in understanding consumer behaviors such as information search and information processing (Bettman \& Park, 1980; Brucks, 1985; Rao \& Monroe, 1988; Sujan, 1985). Product information can be considered as a decision process in which the product class information and rules stored in the memory are used as aggregates or 
as clues in memory scanning to help consumers assess product-related consumption experiences (Guo \& Meng, 2008, p. 260).

In the studies, they have covered three types of information: subjective knowledge, objective knowledge and experience based knowledge. Recently, it has been generally accepted that product information can be categorized into these three types (Brucks, 1985; Dodd, Laverie, Wilcox, \& Duhan, 2005). The first measures the perception of how much someone knows (objective knowledge). The second category measures what a person has in their memory, the amount, the type, or the organization (subjective knowledge). The third category measures the use experience or purchase quantity with the product (Experience-based knowledge). However, in later studies, experience-based knowledge is considered as a preliminary step in the formation of knowledge (Dodd, Laverie, Wilcox, \& Duhan, 2005, p. 6).

When the studies in the literature are examined, Moorman (1994, p.673) showed that subjective knowledge may affect the quality of consumers' preferences in his study. They stated that consumers increased their chances of finding themselves closest to stimuli consistent with subjective knowledge. For example, if consumers believe they are knowledgeable about health, they will increase the likelihood of finding information close to stimuli associated with this information (such as healthy places in the store). Therefore, subjective information stated that instead of searching in the environment, it would affect the search choice between the environments and would direct the effect of subjective information on search. And sources of information at this point are an important issue.

When the literature is examined, it is seen that consumer information sources are divided into three categories. They are dominated by the consumer, the marketplace dominated and neutral sources (Cox, 1967, p. 605). Information sources dominated by the consumer: Interpersonal information sources (mouth to mouth communication), blogs, social media tools, etc. resources; Information sources dominated by the salesman: Promotion, packaging, advertising, etc. resources; Neutral Resources: consumer reports, newspapers, etc. resources.

Chang (2004, p.90) in their study, the product experience for consumers with high knowledge after trying the product, stated that they seem to be decision-makers for the expectations. When product performance does not meet expectations, low discrepancies between personal experiences and advertising estimates indicate that low-knowledge consumers are perceived at higher levels, and because of these differences, high-knowledge 
consumers give more negative reactions to advertising and brand than low-knowledge consumers. In other words, they said that in the process of brand evaluation formation, including exposure to advertising and direct product experiences, advertising plays different roles for users who consume high information and low information. They found that advertising exposure for high-information consumers produced expectations to be evaluated directly from product experiences, and for low-information consumers, exposure to advertising adversely affected the interpretation of subsequent product experiences.

\subsection{The Relationship of Consumer Involvement and Product Knowledge Levels with Purchasing Behaviors}

In the first ten or thirteen articles most frequently seen in the Journal of Consumer Research between 1974 and 1989, great attention was paid to the impact of consumer information on search behavior and information processing (see Brucks 1985; Bettman and Park 1980). Although many studies have found the positive effects of information on search (Brucks 1985, Srinivasan and Ratchford 1991), some have found negative effects (see Beatty and Smith 1987). Bettman (1979), in his study, mentioned the level of involvement as an intermediate variable in the search for information. Considering the literature, many common studies on involvement and product knowledge levels have been discussed.

For example, Hanzaee, Khoshpanjeh and Rahnama (2011), investigated the effect of origin country image, product knowledge levels and product involvement on consumer information search intention and purchase intention. Mobile phone has been selected as product category. The data were collected by a questionnaire from university students. The structural equation modeling of data from 379 participants was used to test the hypothesis 6 . The results show that the country of origin, product knowledge and product involvement have a significant positive impact on consumer information research and purchasing intention (Hanzaee, Khoshpanjeh, \& Rahnama, 2011, p. 625-636).

\section{RESEARCH METHODOLOGY}

So far, the effects of consumer involvement and product knowledge levels on consumer behavior have been discussed. At this point, research will be carried out to examine the relationship between the mentioned subjects. The primary objective of the study is to examine the relationship between consumers' involvement, product knowledge levels with information 
search intention and purchase intention. It was aimed to compare utilitarian products (smart phones) and hedonic products (cosmetics) in terms of demographic variables.

The main mass of the study consisted of students studying at Marmara University in Istanbul. The residence of the researcher was effective in the selection of the province of Istanbul. The sampling method was easy sampling of non-random sampling method was preferred. The sample size of the study was determined as 385 with $95 \%$ confidence interval and $5 \%$ error margin by $\mathrm{n}=\pi(1-\pi) /(\mathrm{e} / \mathrm{Z})^{2}$ formula (Kurtuluş, 1998). However, in order to keep the sample size wide, the number of samples was taken as approximately 500 units. As a result of the 500 questionnaires, 44 questionnaires which were not sufficient were removed and 456 questionnaires were considered valid and participated in the analysis. The data obtained from the survey were transferred to electronic environment using IBM SPSS 20.0 and tested.

\subsection{Models of the Research}

The models of the research are shown below;

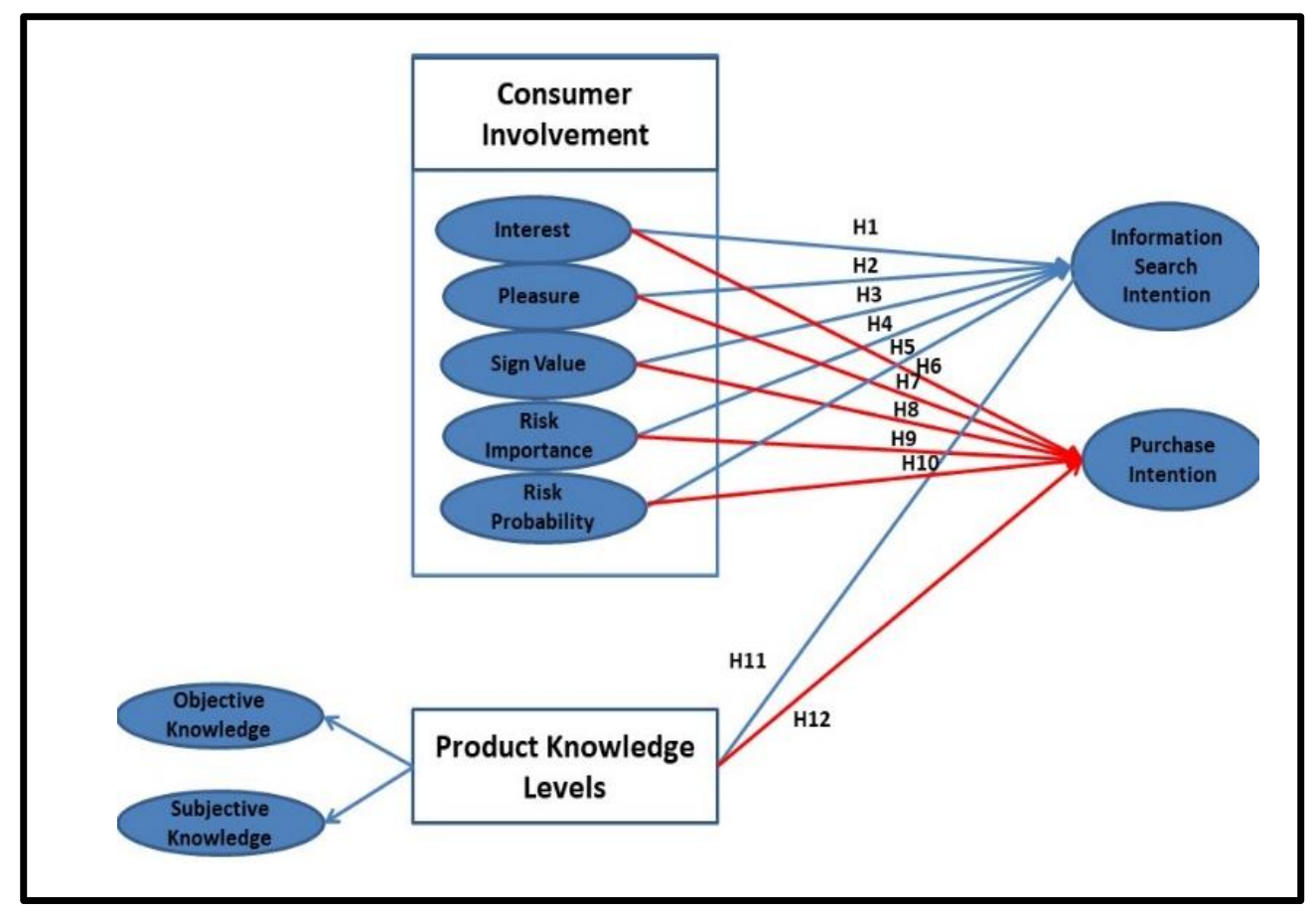

Figure 3. Models of the Research

In line with the aim and model of the research, the research hypotheses were determined as follows and tested at $\alpha=0.05$ significance level.

Mitchell (1981) stated that consumers with high product involvement seek information about the products and then evaluate the product. 
$\mathrm{H} 1.0=$ There is no statistically significant relationship between consumer involvement and information search intention.

$\checkmark \mathrm{H} 1.0 \mathrm{a}=$ There is no statistically significant relationship between interest and information search intention.

$\checkmark \mathrm{H} 1.0 \mathrm{~b}=$ There is no statistically significant relationship between pleasure and information search intention.

$\checkmark \mathrm{H} 1.0 \mathrm{c}=$ There is no statistically significant relationship between sign value and information search intention.

$\checkmark \mathrm{H} 1.0 \mathrm{~d}=$ There is no statistically significant relationship between risk importance and information search intention.

$\checkmark \mathrm{H} 1.0 \mathrm{e}=$ There is no statistically significant relationship between risk probability and information search intention.

Lin and Chen (2006), Hanzaee and Khosrozadeh (2011) stated that consumer involvement had a significant positive effect on consumer purchasing decision (Lin \& Chen, 2006; Hanzaee \& Khosrozadeh, 2011).

$\mathrm{H} 2.0=$ There is no statistically significant relationship between consumer involvement and purchase intention.

$\checkmark \mathrm{H} 2.0 \mathrm{a}=$ There is no statistically significant relationship between interest and purchase intention.

$\checkmark \mathrm{H} 2.0 \mathrm{~b}=$ There is no statistically significant relationship between pleasure and purchase intention.

$\checkmark \mathrm{H} 2.0 \mathrm{c}=$ There is no statistically significant relationship between sign value and purchase intention.

$\checkmark \mathrm{H} 2.0 \mathrm{~d}=$ There is no statistically significant relationship between risk importance and purchase intention. 
$\checkmark \mathrm{H} 2.0 \mathrm{e}=$ There is no statistically significant relationship between risk probability and purchase intention.

At the time of the purchase, the consumer's knowledge of the product will not only affect the behavior of researching the product, but will also affect the decision-making process as well as the intention to purchase (Brucks, 1985). At the same time, Lin and Chen (2006), Hanzaee and Khosrozadeh (2011) stated in their studies that the product knowledge of the consumer positively affects the purchase intention (Lin \& Chen, 2006; Hanzaee \& Khosrozadeh, 2011).

H3.0 = There is no statistically significant relationship between product knowledge levels and information search intention.

$\mathrm{H} 4.0=$ There is no statistically significant relationship between product knowledge levels and purchase intention

\subsection{Data Collection Method of Research}

The questionnaire consists of 2 groups of questions. In the first group, the participants were asked to evaluate the 45 expressions, which consisted of consumer involvement, product knowledge levels, information search intention and purchase intention scales, with 5-point Likert scale. In the second group, there are 5 questions about gender, age, occupational group, education level and monthly personal income aiming to determine the demographic characteristics of the participants. These expressions are translated into 5-Likert scale and listed as 4 1-Strongly Disagree, 2-Disagree, 3-Disagree, Disagree, 4-Agree, 5-Strongly Agree.

Table 1. Scales of the Study

\begin{tabular}{|l|l|l|}
\hline Authors & Variables & Number of Items \\
\hline Flynn \&Goldsmith (1999) & Product Knowledge Levels & 9 item \\
\hline Kapferer \& Laurent (1993) & Consumer Involvement & 16 item \\
\hline Hanzaee \& Khosrozadeh (2011) & Information Search Intention & 4 item \\
\hline Kim, Lee, \& Kim (2004) & Online Information Search Intention & 2 item \\
\hline Dodds, Monroe, \& Grewal (1991) & Purchase Intention & 5 item \\
\hline
\end{tabular}




\subsection{Data Analysis and Research Findings}

Frequency analysis was performed to reveal the demographic characteristics of the participants. The analysis results are shown in Table 2.

Table 2. Distribution of Participants by Demographic Characteristics

\begin{tabular}{|l|c|c|c|}
\hline Variable & Variable Levels & $\mathrm{N}$ & $\%$ \\
\hline Gender & Female & 273 & 59,9 \\
\hline \multirow{3}{*}{ Age } & Male & 183 & 40,1 \\
\cline { 2 - 4 } & $17-24$ & 309 & 67,8 \\
\hline \multirow{4}{*}{ Education Status } & $25-34$ & 135 & 29,6 \\
\cline { 2 - 4 } & $35-44$ & 12 & 2,6 \\
\cline { 2 - 4 } & Undergraduate & 306 & 67,1 \\
\cline { 2 - 4 } & Master and above & 150 & 32,9 \\
\cline { 2 - 4 } & $0-999$ & 42 & 9,2 \\
\cline { 2 - 4 } & $1000-1999$ & 248 & 54,4 \\
\cline { 2 - 4 } & $2000-2999$ & 87 & 19,1 \\
\cline { 2 - 4 } & $3000-3999$ & 45 & 9,9 \\
\cline { 2 - 4 } & $4000-4999$ & 15 & 3,3 \\
\cline { 2 - 4 } & $5000-5999$ & 6 & 1,3 \\
\hline
\end{tabular}

\subsection{Factor and Reliability Analysis Regarding Consumer Involvement Scale}

The factor and reliability analysis carried out regarding the consumer involvement Scale is summarized in Table 3.

Table 3. Factors and Reliability Factors Related to Consumer Involvement Scale Related to Smartphones and Cosmetic Products

\begin{tabular}{|l|l|l|l|l|l|}
\hline \multicolumn{3}{|c|}{ Smartphones } & \multicolumn{3}{c|}{ Cosmetic Products } \\
\hline Factors & $\begin{array}{l}\text { Described } \\
\text { variances (\%) }\end{array}$ & $\begin{array}{l}\text { Cronbach } \\
\text { Alpha } \\
\text { Coefficients }\end{array}$ & Factors & $\begin{array}{l}\text { Described } \\
\text { variances } \\
(\%)\end{array}$ & $\begin{array}{l}\text { Cronbach } \\
\text { Alpha } \\
\text { Coefficients }\end{array}$ \\
\hline $\begin{array}{l}\text { Interest/ } \\
\text { Importance }\end{array}$ & 14,220 & 0,850 & $\begin{array}{l}\text { Interest/ } \\
\text { Importance }\end{array}$ & 6,871 & 0,945 \\
\hline Pleasure & 13,563 & 0,908 & Pleasure & 24,662 & 0,969 \\
\hline Sign Value & 15,830 & 0,974 & Sign Value & 21,583 & 0,956 \\
\hline $\begin{array}{l}\text { Risk } \\
\text { Importance }\end{array}$ & 18,149 & 0,932 & $\begin{array}{l}\text { Risk } \\
\text { Importance }\end{array}$ & 14,508 & 0,970 \\
\hline $\begin{array}{l}\text { Risk } \\
\text { Probability }\end{array}$ & 19,543 & 0,927 & $\begin{array}{l}\text { Risk } \\
\text { Probability }\end{array}$ & 21,926 & 0,964 \\
\hline $\begin{array}{l}\text { Kaiser-Meyer-Olkin Scale Reliability } \\
\text { Sig. }\end{array}$ &, 826 & $\begin{array}{l}\text { Kaiser-Meyer-Olkin } \\
\text { Scale Reliability } \\
\text { Sig. }\end{array}$ &, 867 \\
\hline
\end{tabular}


The values obtained from the reliability analysis after factor analysis of the product information levels, information search intention and purchasing intention variables are given in Table 4.

Table 4. Reliability Analysis of Variables

\begin{tabular}{|l|c|c|}
\hline & $\begin{array}{l}\text { Cronbach Alpha } \\
\text { (SmartPhone) }\end{array}$ & $\begin{array}{l}\text { Cronbach Alpha } \\
\text { (Cosmetic Products) }\end{array}$ \\
\hline Product Knowledge Levels & 0,840 & 0,910 \\
\hline Information Search Intention & 0,943 & 0,859 \\
\hline Purchase Intention & 0,930 & 0,844 \\
\hline
\end{tabular}

\subsection{Regression Analysis}

In the research, it was observed that some dimensions of consumer involvement and product information levels had an effect on the information search intention and purchase intention in the research as a result of regression analysis to determine whether consumer involvement and product information levels have an effect on the intention to seek information and intention to buy. The results of regression analysis are shown in Table 5. and table 6 .

Table 5. Regression Analysis of Consumer Involvement and Product Information Levels

$$
\text { Scales with Information Search Intention (Smartphones) }
$$

\begin{tabular}{|c|c|c|c|c|}
\hline \multicolumn{5}{|r|}{ Smartphones } \\
\hline & $\beta$ & T value & VIF & \multirow{4}{*}{$\begin{array}{l}\text { The factor of interest has an effect of } 60 \% \text { on information } \\
\text { search intention. The factor of pleasure has an effect of } 12,4 \% \\
\text { on information search intention. The factor of Risk probability } \\
\text { has an effect of } 9,9 \% \text { on information search intention. The rate } \\
\text { of disclosure of this factors intention to search for information } \\
\text { was found to be } 40,6 \%\left(\mathrm{R}^{2}=0.406\right) \text {. }\end{array}$} \\
\hline Interest &, 600 & 13,411 & 1,519 & \\
\hline $\begin{array}{l}\text { Pleasaur } \\
\text { e }\end{array}$ &, 124 & 2,867 & 1,408 & \\
\hline $\begin{array}{l}\text { Risk } \\
\text { Probabil } \\
\text { ity }\end{array}$ & ,099 & 2,422 & 1,273 & \\
\hline \multicolumn{4}{|c|}{$\mathrm{R}^{2}: 0,406 \mathrm{R}: 0,637$ P: 0,000} & \multirow{3}{*}{$\begin{array}{l}\text { The factor of product knowledge levels has an effect of } 53.5 \% \\
\text { on information search intention. The rate of disclosure of this } \\
\text { factor's intention to search for information was found to be } 28 \% \\
\left(\mathrm{R}^{2}=0.28\right) \text {. }\end{array}$} \\
\hline $\begin{array}{l}\text { Product } \\
\text { Knowled } \\
\text { ge Levels }\end{array}$ &, 535 & 13,508 & ------ & \\
\hline \multicolumn{4}{|c|}{$\mathrm{R}^{2}: 0,287$ R:0,535 P: 0,000} & \\
\hline
\end{tabular}

In the research about cosmetic products, regression analysis was performed in order to determine whether the consumer involvement, product knowledge levels variables have an effect on the intention to search information. Since the correlation numbers of interest and hedonic value variables were greater than 0.70 , these variables were analyzed individually by regression analysis. In the research, it was observed that the consumer involvement had an effect on the intention of search information as a result of regression analysis to determine whether consumer interest had an effect on the intention of search information. In the first 
regression analysis, the $\mathrm{p}$ value of the risk probability factors higher than 0.05 indicates that these factors do not have a significant effect on the information intention factor. As this variable did not provide a significant contribution to the model, the regression analysis was performed again by subtracting from the model. The results of the regression analysis are shown in Table 6. The results were statistically significant.

Table 6. Regression Analysis of Consumer Involvement and Product Information Levels Scales with Information Search Intention (Cosmetic Products)

\begin{tabular}{|c|c|c|c|c|}
\hline \multicolumn{5}{|r|}{ Cosmetic Products } \\
\hline & $\beta$ & t Value & VIF & \multirow{12}{*}{$\begin{array}{l}\text { The factor of interest has an effect of } 81,8 \% \text { on information } \\
\text { search intention. The rate of disclosure of this factors intention } \\
\text { to search for information was found to be } 66,9 \%\left(\mathrm{R}^{2}=0,669\right) \text {. } \\
\text { The factor of pleasure has an effect of } 74,5 \% \text { on information } \\
\text { search intention. The rate of disclosure of this factors intention } \\
\text { to search for information was found to be } 55,6 \%\left(\mathrm{R}^{2}=0,556\right) \text {. } \\
\text { The factor of sign value has an effect of } 21,7 \% \text { on information } \\
\text { search intention. The factor of Risk importance has an effect o } \\
34,2 \% \text { on information search intention. The rate of disclosure o } \\
\text { this factors intention to search for information was found to be } \\
15,6 \%\left(\mathrm{R}^{2}=0.156\right) \text {. } \\
\text { The factor of product knowledge levels has an effect of } 67,4 \% \\
\text { on information search intention. The rate of disclosure of this } \\
\text { factor's intention to search for information was found to be } \\
45,5 \%\left(\mathrm{R}^{2}=0.455\right) \text {. }\end{array}$} \\
\hline Interest & 818 & 30,277 & ----- & \\
\hline \multicolumn{4}{|c|}{$\begin{array}{lll}\mathrm{R}^{2}: 0,669 & \mathrm{R}: 0,818 & \mathrm{P}: 0,000\end{array}$} & \\
\hline & & & & \\
\hline Pleasure & ,745 & 23,822 & $-\cdots--$ & \\
\hline \multicolumn{4}{|c|}{$\mathrm{R}^{2}: 0,556$ R:0,745 P: 0,000} & \\
\hline Sign Value & 217 & 5.015 & 1003 & \\
\hline & 342 & 7,899 & 1,003 & \\
\hline Importance & & & & \\
\hline \multicolumn{4}{|c|}{$\mathrm{R}^{2}: 0,156 \quad \mathrm{R}: 0,394 \quad \mathrm{P}: 0,000$} & \\
\hline & & & & \\
\hline $\begin{array}{l}\text { Product } \\
\text { Knowledge } \\
\text { Levels } \\
\end{array}$ & 674 & 19,460 & \begin{tabular}{|l|l}
----- \\
\end{tabular} & \\
\hline, 455 & 4 & & & \\
\hline
\end{tabular}

Table 7. Regression Analysis of Consumer Involvement and Product Information Levels Scales with Purchase Intention (Smartphones)

\begin{tabular}{|c|c|c|c|c|}
\hline \multicolumn{5}{|c|}{ Smartphones } \\
\hline & $\beta$ & T value & VIF & \multirow{7}{*}{$\begin{array}{l}\text { The factor of interest has an effect of } 59 \% \text { on purchase } \\
\text { intention. The factor of pleasure has an effect of } 16 \% \text { on } \\
\text { purchase intention. The factor of Risk probability has an } \\
\text { effect of } 18,2 \% \text { on purchase intention. The rate of } \\
\text { disclosure of this factors to purchase intention was } \\
\text { found to be } 41,7 \%\left(\mathrm{R}^{2}=0,417\right) \text {. } \\
\text { The factor of product knowledge levels has an effect of } \\
51,5 \% \text { on purchase intention. The rate of disclosure of } \\
\text { this factor's to purchase intention was found to be } 26,5 \% \\
\left(\mathrm{R}^{2}=0.265\right) \text {. }\end{array}$} \\
\hline Interest &, 590 & 13,311 & 1,519 & \\
\hline Pleasaure &, 160 & 3,748 & 1,408 & \\
\hline Risk Probability & 182 & 4,485 & 1,273 & \\
\hline \multicolumn{4}{|c|}{$\mathrm{R}^{2}: 0,417$ R:0, 646 P: 0,000} & \\
\hline $\begin{array}{l}\text { Product } \\
\text { Knowledge Levels }\end{array}$ &, 515 & 13,508 & ------ & \\
\hline \multicolumn{4}{|c|}{$\mathrm{R}^{2}: 0,265$ R:0,515 P: 0,000} & \\
\hline
\end{tabular}

In the research about cosmetic products, regression analysis was performed in order to determine whether the consumer involvement, product knowledge levels variables have an 
effect on the purchase intention. Since the correlation numbers of interest and hedonic value variables were greater than 0.70 , these variables were analyzed individually by regression analysis. In the research, it was observed that the consumer involvement had an effect on the intention of search information as a result of regression analysis to determine whether consumer interest had an effect on the purchase intention. In the first regression analysis, the $\mathrm{p}$ value of the risk probability factors higher than 0.05 indicates that these factors do not have a significant effect on the purchase intention factor. As this variable did not provide a significant contribution to the model, the regression analysis was performed again by subtracting from the model. The results of the regression analysis are shown in Table 8 . The results were statistically significant.

Table 8: Regression Analysis of Consumer Involvement and Product Information Levels Scales with Purchase Intention (Cosmetic Products)

\begin{tabular}{|c|c|c|c|c|}
\hline \multicolumn{5}{|c|}{ Cosmetic Products } \\
\hline & $\boldsymbol{\beta}$ & t Value & VIF & The factor of interest has an effect of $80,7 \%$ on purchase \\
\hline Interest &, 807 & 29,082 & --------- & intention. The rate of disclosure of this factors for \\
\hline \multicolumn{4}{|c|}{$\mathrm{R}^{2}: 0,651$ R:0,807 P: 0,000} & purchase intention was found to be $66,9 \%\left(\mathrm{R}^{2}=0,669\right)$. \\
\hline Pleasure & ,711 & 21,570 & --------- & purchase intention. The rate of disclosure of this factors \\
\hline \multicolumn{4}{|c|}{$\mathrm{R}^{2}: 0,506 \mathrm{R}: 0,711$ P: 0,000} & $\begin{array}{l}\text { to purchase intention was found to be } 50,6 \%\left(\mathrm{R}^{2}=\right. \\
0,506) \text {. }\end{array}$ \\
\hline Sign Value & ,369 & 8,549 & 1,003 & purchase intention. The factor of Risk importance has an \\
\hline Risk Importance &, 177 & 4,116 & 1,003 & effect of $17,7 \%$ on purchase intention. The rate of \\
\hline \multicolumn{4}{|c|}{$\mathrm{R}^{2}: 0,160 \mathrm{R}: 0,400$ P: 0,000} & $\begin{array}{l}\text { disclosure of this factors to purchase intention was } \\
\text { found to be } 16 \%\left(\mathrm{R}^{2}=0,160\right) \text {. }\end{array}$ \\
\hline & & & & The factor of product knowledge levels has an effect of \\
\hline $\begin{array}{l}\text { Product } \\
\text { Knowledge Levels }\end{array}$ &, 515 & 12,788 & ------- & $\begin{array}{l}51,5 \% \text { on purchase intention. The rate of disclosure of } \\
\text { this factor's for purchase intention was found to be }\end{array}$ \\
\hline \multicolumn{4}{|c|}{$\mathrm{R}^{2}: 0,265$ R:0,515 P: 0,000} & \\
\hline
\end{tabular}

\section{CONCLUSION AND RECOMMENDATIONS}

The result of the study shows that there is a significant statistical relationship between consumer involvement and product knowledge levels with information search intention and purchase intention. As a result, consumers should be considered by marketers who want to increase their profits by searching for more information about products or by increasing their intention to search and acquire information as interested. Knowing the different factors that promote consumer buying effectiveness can help marketers design appropriate sales techniques and responses. Businesses should follow how consumer motivation and decision strategies 
differ between products that differ according to the importance or involvement level they need for the consumer and marketing efforts should be emphasized at this point.

According to the findings of the research, high hedonic values of women in cosmetic products and men in smart phone products group will attract the attention of brands. Since hedonic value is one of the key factors in making a purchase decision and is closely related to products, marketers are encouraged to better engage with consumers 'emotional, engaging, and pleasure-based needs, using engaging advertisements to stimulate consumers' emotions (with the product's enjoyment feature) to attract increasing new consumers today It may be useful.

Moreover, the sign value of the products is a noteworthy factor of the intention to search for information with the possibility that they will reflect the personality of the consumer or create their image as they desire before the purchase decisions. Marketing managers should try to learn about images of consumers in order to adapt their products or brands with the personal image of their target consumers and use this information to create a strong personality for their brands.

The results of the study showed that perceived risk probability factor was related to information search intention. The fact that these factors have a linear inverse relationship indicates that there is a decrease in purchasing intentions with increased perceived risk. Thus, active marketers in this area should take effective measures to understand the risks and determine negative factors from the consumer's point of view and try to minimize them. Marketers should take into account the rapid growth of technology, the fierce competition among existing brands in the market, and that many brands and models in the market can satisfy the functional needs of consumers because of the risk of external features in electronic devices such as smartphones. Thus, the functional risk of such products is reduced. Rather, it is more important to understand the social and psychological differences and emotional risk between existing brands. To reduce the probability of perceived risk, consumers consider brands that they have had positive experience with before. Therefore, marketers should try to create, maintain and develop the positive image of their brands by emphasizing important features. The perceived risk can be expected to be reduced by the fact that information sources (ewomms, opinion leaders, etc.) who experience more products share their positive experiences. In this way, companies or brands not only distinguish their products from their competitors, but also reduce the perceived risk of products and affect consumers' purchasing decisions. 
In the other hand, the presence of counterfeit cosmetic products in the market or the fact that the cosmetic product received will not meet the expectations is likely to increase the importance of perceived risk. For this reason, companies or brands may look at demographic variables (age, gender, education or income) at this point and turn to more descriptive and satisfactory marketing efforts in groups where risks increase.

Another important issue we will consider is the impact of the product knowledge level of consumers on purchasing decisions. Based on the results of the research, it is concluded that by storing the information obtained from experience or secondary sources, it will constitute an seek information search intention and purchase intention again. The most common problem that companies face is the missing or incorrect information that customers have about the products. Therefore, being able to see customers' concerns and provide consumers with accurate information about the product is an important point for consumer behavior. Nowadays, the fact that companies constantly talk about themselves does not have much effect on consumers. Positive or negative comments and thoughts made by others about the product have an important effect on this point. In this case, companies should prevent any negative thoughts that may arise by following consumer suggestions and complaints. Because the results of the research show that the knowledge that consumers have about the products is related to information search intention or purchase intention. Product information levels refer to the consumer's level of awareness and understanding of a product and are measured by the amount of purchase, use and information stored in memory. Based on the research results, companies are encouraged to make more efforts to better inform consumers about the products. In addition to the impact on purchase intention, consumers with a higher level of knowledge about a particular product show that they are less likely to worry about the use of the product. The information process can be provided using various media channels.

This study has some suggestions in the academic field. First, future researchers can include a single product group in their work. In the smartphone or cosmetic product group, the most preferred brands can be identified, researched or compared. Another issue that needs to be researched is that most of the research carried out in relation to involvement concerns consumer goods. Further work on the services is recommended. Last but not least, the big data in marketing and what content is most effective at every stage of the sales cycle, and how it is valued in Customer Relationship Management (CRM) systems. As the largest data category of marketing, value can be obtained through behavioral, behavioral and operational measurements 
from sources such as marketing campaigns, sales points, websites, customer surveys, social media, online communities and loyalty programs. At this point, consumer involvement with products and the value of data marketing $(\mathrm{CRM})$ can be handled together.

As with all studies, there are several limitations that affect the reliability of the findings of the study. The sample was limited to the segment of university students studying in Istanbul. The results of the study cannot be applied to other smartphone or cosmetics buyers. This limits the generalization of the findings. Students in other provinces in Turkey have different involvement and product knowledge level may differ as a result of their relationship with the intention of information search and purchase intention. 


\section{REFERENCES}

Beatty, S. E., \& Smith, S. M. (1987). External Search Effort: An Investigation Across Several Product Categories. Journal of Consumer Research 14 (1), 83-95.

Bettman, J. R. (1979). Information Processing Theory of Consumer Choice. AddisonWesley Pub. Co.

Bettman, J. R., \& Park, C. W. (1980). Effects of Prior Knowledge And Experience And Phase of The Choice Process On Consumer Decision Processes: A Protocol Analysis. Journal of Consumer Research, vol.7 (December), 234-248.

Bloch, P. H., \& Richins, M. L. (1983). A Teoretical Model for the Study Product Importance Perceptions. Journal of Marketing Vol.47 (Summer1983), 69-81.

Brucks, M. (1985). The Effects of Product Class Knowledge On Information Search Behavior. Journal of consumer research, 1-16.

Bruwer, J., \& Buller, C. (2012). Consumer Behavior Insights, Consumption Dynamics, and Segmentation of the Japanese Wine Market. Journal of International Consumer Marketing, 24(5), 338-355.

Cabañero, C. P. (2006). Consumer Involvement in Goods And Service Purchases. Esic Market, 73-91.

Chang, C. (2004). The interplay of product class knowledge and trial experience in attitude formation. Journal of Advertising, 33(1), 83-92.

Choubtarash, N., Mahdieh, O., \& Marnani, A. B. (2013). The Study of The Relationship Between Consumer Involvement And Purchase Decision (Case Study: Cell phone). Interdisciplinary Journal of contemporary Research in business, 276-296.

Cox, D. (1967). Risk Handling in Consumer Behavior -An Intensive Study of Two Cases. in Cox, P.F. (Ed.), Risk Taking and Information Handling in Consumer Behavior, Graduate School of Business Administration, Harvard University, Boston, 34-81.

Day, G. S. (1970). Buyer Attitudes And Brand Choice Behavior. New York: Free Press.

Dhar, R., \& Wertenbroch, K. (2000). Consumer Choice Between Hedonic and Utilitarian Goods. Journal of Marketing Research, 60-71.

Dodd, T. H., Laverie, D. A., Wilcox, J. F., \& Duhan, D. F. (2005). Differential Effects of Experience, Subjective Knowledge And Objective Knowledge on Sources of Information Used in Consumer Wine Purchasing. Journal of Hospitality \& Tourism Research, 29(1)., 3-19.

Dodds, W. B., Monroe, K. B., \& Grewal, D. (1991). Effects of Price, Brand, and Store Information on Buyers' Product Evaluations . Journal of Marketing Research, 307-319.

Flynn, L. R., \& Goldsmith, R. E. (1999). A short, Reliable Measure of Subjective Knowledge. Journal of Business Research, 57-66.

Gamble, P. R., \& Blackwell, J. (2001). Knowledge Management: A State of The Art Guide. Kogan Page Publishers.

Guo, L., \& Meng, X. (2008). Consumer Knowledge and Its Consequences: An International Comparison. International Journal of Consumer Studies , 260-268.

Hanzaee, K. H., \& Khosrozadeh, S. (2011). The Effect of the Country-of-Origin Image, Product Knowledge and Product Involvement on Information Search and Purchase Intention. Middle-East Journal of Scientific Research 8 (3), 625-636.

Hanzaee, K. H., \& Mirvaisi, M. (2011). Customer orientation of service employees: a case study of Iranian Islamic banking (based on COSE model). International Journal of Marketing Studies, 130-145.

Hanzaee, K. H., Khoshpanjeh, M., \& Rahnama, A. (2011). Evaluation of the Effects of Product Involvement Facets on Brand Loyalty. African Journal of Business Management, 5(16), 6964-6971. 
Higie, R. A., \& Feick, L. F. (1989). Enduring Involvement: Conceptual and Measurement Issues. Advances in Consumer Research, 690-696.

Houston, M. J., L., \& Rothschild, M. (1977). A Paradigm for Research on Consumer Involvement. Graduate School of Business, University of Wisconsin-Madison, 1-35.

Kandemir, G. (2018). Tüketici İlgilenim ve Ürün Bilgi Düzeylerinin Satın Alma Kararları Üzerindeki Rolüne İlişkin Bir Araştırma. Marmara Üniversitesi, Sosyal Bilimler Enstitüsü, Yayınlamış Yüksek Lisans Tezi.

Kapferer, J. N., \& Laurent, G. (1993). Further Evidence on the Consumer Involvement Profile: Five Antecedents of Involvement. Psychology \& Marketing, 347-355.

Kapferer, J.-N., \& Laurent, G. (1985). Consumer Involvement Profiles:A New Practical Approach to Consumer Involvement. Journal of Advertising Research Volume 25, No. 6, December 1985/January 1986, 48-56.

Kim, J., Lee, H., \& Kim, H. (2004). Factors Affecting Online Search Intention and Online Purchase Intention. Seoul Journal of Business, 27-48.

Kotler, P., \& Armstrong, G. (2010). Principles of Marketing. Pearson Education.

Kotler, P., \& Keller, K. (2012). Marketing Management 14e.

Krugman, H. E. (1962). An Application of Learning Theory to TV Copy Testing. Public Opinion Quarterly, 626634.

Krugman, H. E. (1965). The Impact of Television Advertising: Learning without Involvement. Public Opinion Quarterly, 29(3), 349-356.

Krugman, H. E. (1966). The measurement of advertising involvement. Public Opinion Quarterly, 30(4), 583-596.

Krugman, H. E. (1977). Memory Without Recall, Exposure Without Perception. Journal of Advertising Research.

Kurtuluş, K. (1998). Pazarlama araştırmaları. İstanbul Üniversitesi İşletme Fakültesi.

Laurent, G., \& Kapferer, J.-N. (1985). Measuring Consumer Involvement Profiles. Journal of Marketing Research, 41-53.

Lin, L. Y., \& Chen, C. S. (2006). The influence of the country-of-origin image, product knowledge and product involvement on consumer purchase decisions: an empirical study of insurance and catering services in Taiwan. Journal of consumer Marketing, 23(5), 248-265.

Malhotra, N. K. (2002). Basic Marketing Research: Applications to Contemporary Issues. Upper Saddle River, NJ: Pearson Education, Inc.

McGill, T., \& Klobas, J. (2008). User developed application success: sources and effects of involvement. Behaviour \& Information Technology, 27(5), 407-422.

Michaelidou, N., \& Dibb, S. (2006). Product Involvement: An Application in Clothing. Journal of Consumer Behaviour, 5(5), 442-453.

Michaelidou, N., \& Dibb, S. (2008). Consumer Involvement: A New Perspective. The Marketing Review, 8(1), 83-99.

Mitchell, A. A. (1981). The dimensions of advertising involvement. ACR North American Advances.

Mittal, B. (1989). Measuring Purchase- Decision İnvolvement. Psychology \& Marketing, 147-162.

Park, C. W., \& Moon, B. J. (2003). The relationship between product involvement and product knowledge:

Moderating roles of product type and product knowledge type. Psychology \& Marketing, 20(11), 977997.

Rao, A. R., \& Monroe, K. B. (1988). The Moderating Effect of Prior Knowledge on Cue Utilization in Product Evaluations. Journal of Consumer Research., 253-264. 
Rothschild, M. L. (1984). Perspectives on Involvement: Current Problems and Future Directions. in NA - Advances in Consumer Research Volume 11, eds. Thomas C. Kinnear, Provo, UT : Association for Consumer Research, 216-217.

Sherif, M., \& Cantril, H. (1947). The Psychology of Ego-Involvement. New York: Wiley.

Solomon, M. R. (1994). Consumer Behavior Buying, Having, and Being. Ally and Bacon.

Solomon, M. R. (2010). Consumer behavior: Buying, having, and being . London: Pearson Education.

Solomon, M., Bamossy, G., Askegaard, S., \& Hogg, M. (1999). Consumer Behaviour: A European Perspective. New Yersey, ZDA: Prentice Hall Inc.

Tekin, G., Yiltay, S., \& Ayaz, E. (2016). The Effect of Brand Image on Consumer Behaviour: Case Study of Louiss Vuitton-Moet Hennessy. Internatonal Journal of Academic Value Studies, 2(1), 1-24.

Sujan, M. (1985). Consumer Knowledge: Effects on Evaluation Strategies Mediating Consumer Judgments. Journal of Consumer Research, 31-46.

Zaichkowsky, J. L. (1978). Involvement and the Price Cuei. Advances in Consumer Research, 323-327.

Zaichkowsky, J. L. (1985). Measuring the Involvement Construct. Journal of Consumer Research, Vol. 12 (December), 341-352.

Zaichkowsky, J. L. (1986). Conceptualizing Involvement. Journal of Advertising, Vol. 15, No. 2, 4-34.

Zaichkowsky, J. L. (1987). The Emotional Affect of Product Involvement. NA-Advances in Consumer Research, 32-35. 